\title{
Test of Asymmetric Information in the Nepalese Reinsurance Market
}

\section{Rajendra Maharjan ${ }^{1}$}

${ }^{1} \mathrm{PhD}$ Scholar, Midwestern University, Shurkhet, Nepal, Corresponding email: rajendra.maharjan707@gmail.com

Received date: October 20, 2021

Revised date: November 18, 2021

Accepted date: December 16, 2021

\section{Cite this paper}

Maharjan, R. (2021). Test of Asymmetric Information in the Nepalese Reinsurance Market. International Research Journal of Management Science, vol.6(1), pp. 74-91

\begin{abstract}
Background: The imperfect information can cause an imbalance of power which may lead to market failure thus collection of information is very essential in today's business world therefore, the availability of the correct and accurate information is very crucial for making sound economic decisions. Thus, information asymmetry has been a very pertinent issue where economic transaction takes place insurance market is not far behind. As, reinsurance provides huge indirect capital to the insurance industry, providing correct information's like premium earned, claim by the insurer to the reinsurer's for fair pricing of reinsurance premium along ensuring top rated reinsurance company remain in Nepalese insurance industry.
\end{abstract}

Objectives: This study aims to examine whether there remains asymmetric information in Nepalese insurance market with reinsurer's perspective in different portfolios such as fire, marine; motor, engineering and miscellaneous as well as combining all portfolio in aggregate.

Methods: The stud uses descriptive and causal relation research design. Further, the study uses secondary data of 14 nonlife insurance from $2008 / 09$ to 2018 / 19 with 168 firm year observations

Result: Results of the study revealed that that only in fire, marine and overall portfolios there exists strong asymmetric information. Rest of the portfolio like motor, engineering and miscellaneous there is no evidence of existence of asymmetric information.

Conclusion: Existence of asymmetric information is mostly an inevitable part as one party always tries to avoid information to others for the sake of benefit. However, the existence of asymmetric information to a large extent may lead to unhealthy relations between the parties and may bring the cold war distortion of relations. Thus, the finding of the studies is beneficial to the Nepalese nonlife insurers as insurers need to provide correct and accurate information to the reinsures

Implication: To cope with asymmetric information in the Nepalese insurance industry, this study provides strong evidence to provide correct and accurate information's to the reinsurers else top rated reinsurers might withdraw their presence from the Nepalese market which will have adverse effect in the insurance industry.

Keywords: Asymmetric Information, Reinsurance, Insurance, Adverse Selection, Moral Hazard 


\section{Introduction}

Collection of information is very essential in today's business world and the availability of the accurate information is crucial for making sound economic decisions. There is a constantly growing body of empirical literature studying the existence of asymmetric information in insurance markets (Cohen and Spiegelman, 2010; Einav, Finkelstein, and Levin, 2010; Chiappori and Salanie, 2015). Standard ' economic theory predicts that under private information, insurance claims and coverage are positively correlated. On the one hand, the empirical studies in some competitive insurance markets provide no evidence of asymmetric information (Dionne et al. (2001). Despite the substantial literature on empirical analyse, to date no consensus has been reached as to whether asymmetric information exists or not (Wei and Wei, 2018).

The imperfect information can cause an imbalance of power which may lead to market failure. Thus, information asymmetry has been a very important issue in any market over the years. The insurance market is no exception to this (Akerlof 1970; Su \& Spindler 2013). Prior empirical studies by Hedengren and Stratmann (2016) and Aarbu (2017) have focused on examining the existence of asymmetric information in different insurance markets but very few studies conducted on investigation of the asymmetric information issue in reinsurance markets except for Adams and Diacon (2006), Yan (2013), Garven, Hilliard, and Grace (2014) and Yan and Hong (2015).

Insurance is gradually developing in Nepal. Recent reports by Beema Samiti indicate that there is 23 percent penetration in life insurance and 8 percent in nonlife insurance indicating there is a wide prospect of the insurance and reinsurance market in Nepal (Beema Samiti, 2020). With this evidence, the level of insurance penetration is quite low in Nepal. Various reasons behind it might be lack of awareness, low income, slow claim payment by insurance companies, miss-selling in life insurance (Maharjan, 2019). In the recent past the introduction of 13 insurance companies (10 life insurance companies and 3 nonlife insurance companies) further created intense unhealthy competition in the Nepalese insurance market creating an unfavorable environment for asymmetric information and moral hazard in the insurance market. The reinsurance market is based on the performance of the insurance company and the availability of correct and accurate information is key for reinsurers as reinsurance is also based on following the fortune clause.

Reinsurance is one of the best mechanisms to transfer the risk and manage the portfolio risk of the insurance companies. The transfer of risk in the form of reinsurance is widely practiced around the globe by the insurance companies in both developed and developing countries and Nepal is no exception. Low capital (life Rs. 200 billion and nonlife Rs. 100 billion), resulting low risk bearing capacity, regulatory compliance, unable to exert the strong financial loss due to catastrophe like big floods, fire, earthquake are some of the prominent causes or transferring risk by the insurance companies in the form of reinsurance. If asymmetric information exists in reinsurance markets, there should be a positive relation between loss ratio and reinsurance ratio (Chen \& Shiu, 2020). 
Empirical studies show that there has been ample evidence of the study carried out in developed and developing countries but similar study is lacking in the Nepalese context. Moreover previous studies have not tested existence of asymmetric information in different portfolio life, fire, marine motor, engineering thus, this research intends to explore the existence of asymmetric information in different portfolios. The finding of this study will be beneficial for reinsurers that are actively participating in the Nepalese insurance market. Further the finding of the study is expected to provide more cautious underwriting by the company especially for the business ceded by high loss ratios. The regulators might take some effective measures for better regulations to the insurers to mitigate such phenomenon which ultimately build the confidence among the reinsurers operating in the Nepalese insurance market. Thus, the study has a great social impact. As the insurer keeps on thinking that hiding the information can make a good recovery from the reinsurer which in turn, leads to adverse selection and moral hazard from reinsurer perspective. If the situation continues for a long time, new and renowned top rated reinsurers might leave the Nepalese insurance market. Then, insurance companies tend to gradually move towards African market for low rated reinsures with fewer documentation. In turn it might lead to increment in credit risk to the insurance company and might face huge financial loss in the long run due to being unable to recover the claim on time.

Moreover, the reinsurance supply in the Nepalese insurance industry is mainly dominated by foreign international reinsurers and those foreign reinsurers may not be that closely familiar with Nepalese market as reinsurance arrangement is mainly dealt by brokers. Doherty and Smetters (2005) indicate that the extent of moral hazard increases with the increase of reinsurance coverage. Thus, the prime objective of this research is to examine the existence of asymmetric information in Nepalese nonlife reinsurance market by using panel data. The reminder of the paper is organized as follows. The next section of the article deals with the research problem followed by literature review, research methodology and finding of the study.

Almost all economic transactions involve information asymmetric. Asymmetric information leads to market failure. It occurs when one party to an economic transaction possesses greater material knowledge than the other party; however reverse dynamic is also possible. Asymmetric information's result in moral hazard and adverse selection (Akerlof, et. al. 2001). Crocker and Snow (2016) argue that, in theory, risk classification can enhance the economic efficiency of insurance markets with asymmetric information and mitigate the adverse selection that arises when insurance applicants are better informed about their riskiness than insurers.

In reinsurance settings, insures that purchase more reinsurance may tend to have fewer incentives for loss prevention. Primary insurers are familiar with the business that they cede out (Jean-Baptiste and Santomero 2000), but reinsurers could not observe primary insurers' loss prevention efforts after reinsurance contracting (Bond and Crocker 1997). Adverse selection arises from policyholders' hidden information about the probability of filing a loss and the distribution of loss severity (Cohen and Siegelman 2010). Previous study has basically more focus on exploring the existence of asymmetric information 
focusing on individual portfolios like automobiles and in the health sector. This study tries to explore existence of asymmetric information's in basically five major portfolio like, Property (fire), marine, motor, engineering and miscellaneous and overall portfolio and comparing which portfolio is more severe in terms of existence of asymmetric information by considering the cross section data of sample nonlife insurance companies. Thus, the study has a clear contribution on the topic.

The implications part of this would be policy revision probably reinsurance directives issued by Beema Samiti. The present reinsurance directive issued by Beema Samiti were

1. Reinsurance directive, 2008 for life Insurance Company

2. Reinsurance directive, 2008 for nonlife insurance company

3. Reinsurance directive, 2015 recently revised in 2019 for a local reinsurance company

Where the major focus is on the part of proper reinsurance arrangement of an insurance company but not much on the disclosure of statistics by the insurance/reinsurance company to the reinsurance company which might lead to charging the low insurance premium and bearing high loss by Reinsurance Company. The ultimate consequences remains if the scenario continues the renowned reinsurers will gradually leave Nepalese market and the Nepalese insurer move towards soft reinsurance market where there is loss premium, fewer documents, low graded reinsurers leading to falling to get reinsurance claim resulting in the heavily loss in the insurance company. Thus, the study will contribute socially in terms of minimizing the existence of asymmetric information in the insurance market which ultimately leads to the longer term existence of new and renowned reinsurers attracting to operate in the Nepalese insurance market.

\section{Literature Review}

Information asymmetry has been a vital issue often discussed in the insurance market over the years (Akerlof 1970; Su and Spindler 2013; Jean-Baptiste and Santomero 2000). The scope and more attention towards the issue of many scholars seems to have drawn after the first seminal work by Akerlof (1970), extensive attention among the economic agents has been drawn in informational asymmetries. Many prior empirical studies such as Hedengren and Stratmann (2016) and Aarbu (2017), examine whether asymmetric information exists in different insurance markets. The asymmetric information phenomenon has been extensively examined in insurance markets (Jean-Baptiste \& Santomero 2000). The existence of asymmetric information basically results in moral hazard and adverse selection. In reinsurance settings, insures that purchase more reinsurance may tend to have fewer incentives for loss prevention. In reinsurance settings, primary insurers cede the business that exceed their underwriting capacity to reinsurers. Although reinsurers are highly specialized in underwriting and can mitigate asymmetric information by specifying deductibles and coinsurance rates in reinsurance contracts, there still exists unobservable information that may affect reinsurance premiums such as primary insurers' managers' self-interested behavior. 
Managers have incentives to enhance short-term performance to increase short-term compensation and protect job security because they are monitored by the board and shareholders. Therefore, they have incentives to hide adverse information in order to purchase underpricing reinsurance coverage. Moreover, the reinsurance supply in the Nepalese non-life industry is mainly dominated by foreign international reinsurers and those foreign reinsurers may not be that familiar with the Nepalese non-life sector.

Hypothesis 1: Asymmetric information doesn't exist in the Nepalese reinsurance market Hypothesis 2: Asymmetric informations exist in all portfolio in the Nepalese reinsurance market

This study contributes to the relevant literature in the following ways. First, this study is the first research that examines asymmetric information in Nepalese non-life reinsurance markets. This phenomenon may result from moral hazard and/or adverse selection (Arrow 1963).

\section{Research Methodology}

The study used descriptive cum analytical research. Descriptive analysis is to describe the fact finding. Correlational and regression analysis is use to see the effect of independent variables to dependent variables. The study makes an attempt to explore the issues by taking the sample from non-life insurance companies only. Out of 20 nonlife insurance companies operating in Nepal, only 14 insurance companies are taken as samples based on judgmental sampling. Remaining six companies are not considered in the study companies as out of six companies, Rastriya Beema Company does not have audited financial data, two Indian companies Oriental and National insurance companies are operating as a branch and remaining 3 companies are recently insurance established only 3 years back.

The data applied here are collected from the 14 nonlife insurance companies operating in Nepal. The data used in the study were from 2008/09 to 2019/20 with 168 firm year observations. Data has been collected from 2008/09 as Beema Samiti has issued financial directives in the fiscal year 2008 before that date there has not been uniform financial reporting by insurance companies to Beema Samiti.

The study follows the model previously used by Chen Shiu (2020) and purposed by Cohen and Siegelman (2010) regression model as follows:

$\mathrm{LR}$ it $=\mathrm{a} 0+\mathrm{a} 1{ }^{*}$ Reinsit $+\mathrm{E} \mathrm{A}{ }^{*} \mathrm{CVit}+$ sit + eit

where LRit denotes loss ratio for insurer $i$ at time $t$; 8 Reinsi,t denotes reinsurance ratio for insurer $i$ at time $\mathrm{t}$. $\mathrm{a} 0$ is an intercept term. al measures the effect of reinsurance ratio on loss ratio after controlling the information observable to reinsurers. If the coefficient shows positive and significance, it indicates evidence of asymmetric information. CVit is a vector of control variables, loss ratios possibly 1-year lagged loss ratio, 2-year lagged loss ratio, return on asset, firm size, insurance leverage, age, line-of-business concentration, total premium growth rate and various line-of-business premium growth rate. sit denotes individual or firm effect that does not change with time. eit is a residual term. 
The methods used to analyze the data are interpretive based on results. Further, the study compared and contrasted with the previous study. Further, testing of hypotheses is a key in analysis. Table 1 below describes the variable under considerations and their measurement.

\section{Table 1 : Variables and its measurement}

\begin{tabular}{|c|c|c|}
\hline Variables & Definitions & Sources \\
\hline Loss ratio & $\begin{array}{l}\text { (Direct written losses + reinsurance losses)/(direct } \\
\text { written premium + reinsurance premiums received) }\end{array}$ & Shiu and Hsiao (2014) \\
\hline Reinsurance ratio & $\begin{array}{l}\text { Reinsurance premiums ceded /(direct written } \\
\text { premiums + reinsurance premium received). }\end{array}$ & Shiu and Hsiao (2014) \\
\hline $\begin{array}{l}\text { 1-year lagged loss } \\
\text { ratio }\end{array}$ & 1-year lagged loss ratio. & $\begin{array}{l}\text { Berry Stölzle and Born } \\
\text { (2012) }\end{array}$ \\
\hline $\begin{array}{l}\text { 2-year lagged loss } \\
\text { ratio }\end{array}$ & 2-year lagged loss ratio. & $\begin{array}{l}\text { Berry Stölzle and Born } \\
(2012)\end{array}$ \\
\hline Return on asset & Net income after tax divided by total assets & $\begin{array}{l}\text { Upreti and Adams } \\
(2015)\end{array}$ \\
\hline Firm Size & The natural logarithm of total assets & Adams and Jiang (2016) \\
\hline Insurance leverage & Net premium written/ shareholder equity & Yan (2013) \\
\hline Age & $\begin{array}{l}\text { The natural logarithm of the number of years since a } \\
\text { firm's establishment }\end{array}$ & Adams and Jiang (2016) \\
\hline $\begin{array}{l}\text { Total premium } \\
\text { growth rate }\end{array}$ & The annual growth rate of total written premium & Yan and Hong (2015) \\
\hline $\begin{array}{l}\text { Various line } \\
\text { premium growth } \\
\text { rate }\end{array}$ & $\begin{array}{l}\text { The annual growth rate of various lines written } \\
\text { premiums. }\end{array}$ & Yan and Hong (2015) \\
\hline
\end{tabular}

\section{Dependent Variable}

\section{A. Loss Ratio}

Following Yan and Hong (2015), the study uses loss ratio to measure insurers' extent of ex post risk. The definition of loss ratio is based on Shiu and Hsiao (2014). It is defined as the ratio of direct written losses plus reinsurance losses divided by direct written premium plus reinsurance premiums received.

\section{Main Independent Variables}

\section{A. Reinsurance Ratio}

Based on Shiu and Hsiao (2014), this study defines reinsurance ratio as the ratio of reinsurance premiums ceded divided by direct written premiums plus reinsurance premium received. 


\subsubsection{Control Variables}

It is important to control policyholder's characteristics observable to insurers when examining the existence of asymmetric information in insurance markets. However, the restriction in testing reinsurance asymmetric information is the unavailability of reinsurance contract level data (Yan and Hong 2015). The study therefore cannot control contract level data. Dionne (2013) indicates that adverse selection means that policyholders will have more information of the probability of occurring an accident than insurers have. In addition, moral hazard means the policyholders' hidden behavior and such behavior is correlated with the loss prevention effort, further affecting the probability of occurring an accident. Therefore, the superior information and hidden behavior are correlated with variables that affect expected loss of primary insurers. This study includes the related variables that affect loss ratio based on loss ratio literature.

\section{A. 1-Year and 2-Year Lagged Loss Ratio}

Underwriting cycle is a commonly seen characteristic of the non-life industry. Following Berry Stölzle and Born (2012), the study employ the second order autoregression model, in terms of 1-year and 2-year lagged loss ratio, to control the underwriting cycle in hard and soft markets (Cummins and Outreville 1987; Harrington and Yu 2003). In addition, Wooldridge (2016) indicates that the study could capture the information such as contract level information, affecting dependent variables but hard to be included in the model, by including the lagged terms of the dependent variable.

\section{B. Return on Assets}

Firms with better financial performance are more capable of bearing the unexpected losses. Since these firms have more confidence in investment performance, they may relax their underwriting standard to obtain more funds for investing by collecting more insurance premiums, which is known as cash flow underwriting. Thus, the loss ratio will therefore increase. On the contrary, firms with better financial performance may further invest in loss prevention and mitigation activities. If this is the case, the loss ratio may decrease. Yan (2013) also uses this measure as a control variable of loss ratio ceded. This study follows Upreti and Adams (2015) and defines return on assets as the ratio of net income before taxes divided by total assets.

\section{Firm Size}

The higher the firm size, the lower the bankruptcy cost (Warner 1977). Larger firms generally are more able to tolerate high loss ratios under certain underwriting profitability conditions since they have the economic scale and scope in underwriting expenses (Hardwick, Adams, and Zou 2011). Moreover, since large firms generally have better investment performance, they are more able to tolerate worse underwriting performance. Firm size is defined as the natural logarithm of total assets. 


\section{Insurance Leverage}

Insurers with higher own capital will have higher underwriting capacity and are more able to underwrite higher risk business (Doherty and Garven 1995). In addition, the higher the insurance leverage, the higher the bankruptcy probability (Carson and Hoyt 1995). These insurers are more prone to be monitored by regulators (Yan and Hong 2015). Therefore, insurers with higher insurance leverage will put more efforts into loss prevention and mitigation. The study expects that the relationship between insurance leverage and loss ratio is negative. Insurance leverage is defined as the net premium written divided by shareholders equity.

\section{E. Age}

Insurers that have existed for more operating years generally can accumulate more knowledge on insurance products and markets, compared to newer insurers. These older insurers have better underwriting experience (Adams and Jiang 2016) and are expected to have lower loss ratios. This variable is defined as the natural logarithm of the years since the firm was established.

\section{F. Line-of-Business Concentration}

Insurers with more concentrated businesses usually are riskier (Shiu 2011) and therefore have higher loss ratios. However, insurers that focus more on underwriting certain business lines in which they specialize may lead to a lower loss ratio. The study measures business concentration by a Herfindahl index. It is defined as the sum of squares of the ratio of the written premiums of various lines divided by the total written premium (Upreti and Adams 2015).

\section{G. Total/Various Line Premium Growth Rate}

Aggressive insurers in underwriting tend to experience a rapid growth in premiums written equally imposed to high risk (Yan 2013). Therefore, there exists a positive relationship between premium growth and loss ratios. The study considers annual growth rate of premium as the premium written each year with respect to consecutive increments in premium. 


\section{Empirical Results}

4.1 Univariate Analysis

Table 2 presents summary statistics of the variables that includes number of observations, mean, maximum, minimum and standard deviation of the variables under consideration. During the sample period the overall average loss ratios and reinsurance ratios are 48.56 percent and 54.1 percent respectively while 1 and 2 year lag loss ratios are found to be 47.7 percent and 47.3 percent. The average return on assets is 6 .

Table : 2

Descriptive Statistics

\begin{tabular}{llllll}
\hline & $\mathrm{N}$ & Minimum & Maximum & Mean & Std. Deviation \\
\hline O_LossRatio & 168 & 0.140 & 0.991 & 0.486 & 0.186 \\
O_ReinsRatio & 168 & 0.228 & 0.840 & 0.541 & 0.126 \\
O_1YLossR & 154 & 0.140 & 0.991 & 0.477 & 0.189 \\
O_2YLossR & 140 & 0.140 & 0.991 & 0.473 & 0.192 \\
ROA & 168 & -0.077 & 0.127 & 0.065 & 0.035 \\
Firm_Size & 168 & 18.714 & 22.277 & 20.607 & 0.825 \\
O_InsurLev & 168 & 0.013 & 1.868 & 0.900 & 0.396 \\
Age & 168 & 1.386 & 4.277 & 2.788 & 0.582 \\
O_LBC & 168 & 0.000 & 0.018 & 0.006 & 0.004 \\
O_AnnualPG & 154 & -0.890 & 1.399 & 0.221 & 0.316 \\
F_AnnualPG & 154 & -0.840 & 1.711 & 0.200 & 0.308 \\
Ma_AnnualPG & 156 & -0.912 & 2.594 & 0.203 & 0.422 \\
Mo_AnnualPG & 154 & -0.922 & 2.244 & 0.271 & 0.440 \\
Eng_AnnualPG & 154 & -0.964 & 35.773 & 0.610 & 2.928 \\
Misc_AnnualGIP & 154 & -0.876 & 1.370 & 0.181 & 0.333
\end{tabular}


Table 3 presents the Pearson's correlation matrix. The correlation between loss ratios and reinsurance ratios is 0.077 and is positive. This finding provides preliminary evidence that there is presence of asymmetric information in the Nepalese reinsurance markets.

Table 3: Pearson's Correlations Matrix

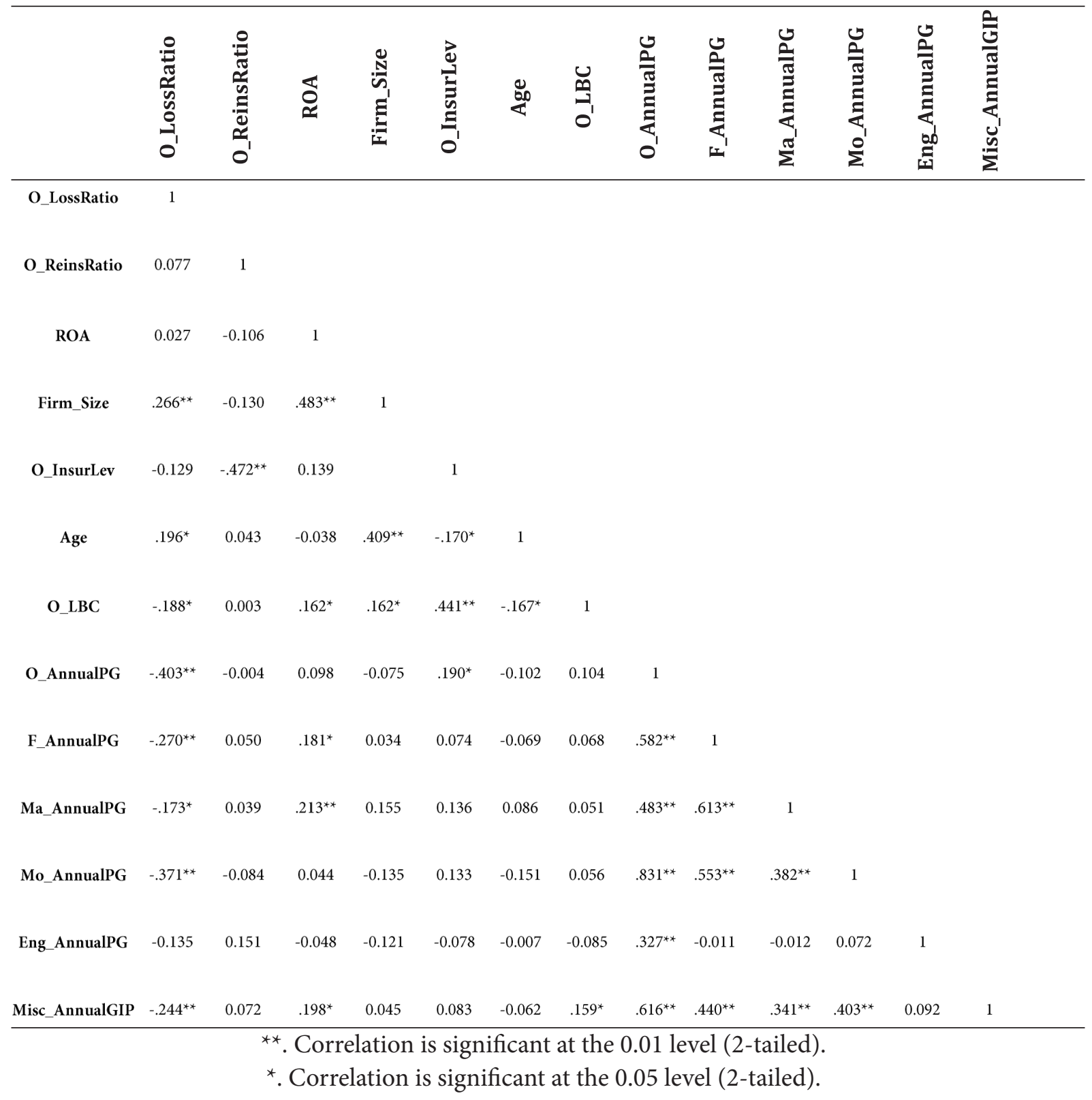


Table 4 presents the results of a multicollinearity test. Since tolerance level is less than 1 but lesser than 0.2 and VIF is less than 10 but not exceeding 4 indicating there is no problem of multicollinearity (Hairet al., 2010).

\section{Table 4: Collinearity Statistics}

\begin{tabular}{|l|c|c|}
\hline \multicolumn{1}{|c|}{ (Constant) } & Tolerance & VIF \\
\hline O_ReinsRatio & 0.576 & 1.723 \\
\hline ROA & 0.698 & 1.433 \\
\hline Firm_Size & 0.712 & 1.404 \\
\hline O_InsurLev & 0.581 & 1.72 \\
\hline Age & 0.497 & 2.012 \\
\hline O_LBC & 0.712 & 1.405 \\
\hline O_AnnualPG & 0.559 & 1.789 \\
\hline O_1YLossR & 0.911 & 1.098 \\
\hline O_2YLossR & 0.822 & 1.217 \\
\hline
\end{tabular}

\section{A. Fire Portfolio: $\quad 4.2$ Multiple Regression Analysis}

Table 5 presents the results for OLS regression one without lag independent variables of loss ratios and one with lag independent variables of loss ratios.

Table 5: Fire Portfolio

\begin{tabular}{lllll}
\hline & Model1 & & Model2 & \\
\hline & Coefficient & Standard Errors & Coefficient & Standard Errors \\
(Constant) & $-2.749^{* * *}$ & 1.018 & $-2.430^{*}$ & 1.284 \\
F_ReinsRatio & $0.355^{*}$ & 0.209 & 0.355 & 0.223 \\
ROA & $2.645^{* *}$ & 1.107 & $2.467^{* *}$ & 1.188 \\
Firm_Size & $0.121^{* *}$ & 0.054 & 0.103 & 0.067 \\
O_InsurLev & -0.117 & 0.1 & -0.101 & 0.116 \\
Age & $0.119^{*}$ & 0.072 & 0.123 & 0.081 \\
O_LBC & 0.452 & 9.612 & 0.49 & 11.099 \\
F_AnnualPG & $-0.202^{*}$ & 0.11 & -0.16 & 0.117 \\
F_1YLossR & & & $0.236^{* * *}$ & 0.089 \\
F_2YLossR & & & $-0.163^{*}$ & 0.091 \\
\hline N & 168 & & 120 & \\
Adjusted R & 0.203 & & 0.232 & \\
P Value & $.000 \mathrm{~b}$ & & $.000 \mathrm{~b}$ & \\
F Value (P value) & 5.303 & & 4.37 & \\
\hline
\end{tabular}


Since reinsurance ratios are positive and significant with the dependent variable loss ratios. This indicates that in the fire portfolio the study fails to accept the null hypothesis. This result strongly reveals the existence of asymmetric information in the fire portfolio. The finding of the study is consistent with Yan and Hong (2015).

\section{B. Marine Portfolio}

Table 6 presents the results for OLS regression of marine portfolios. Reinsurance ratio is positive and significant in both models at 1 percent level indicating there exists asymmetric information in marine portfolios. One year lag loss ratios and two yer lag ratios are positive but 2 year lag is significant at 10 percent indicating there is presence of asymmetric information in marine portfolio. The adjusted $\mathrm{R}$ square value ranges from 31.7 to 34.3 indicating more than 30 percent in variation in loss ratios is determined by the variables under consideration.

Table 6: Marine Portfolio

\begin{tabular}{|c|c|c|c|c|}
\hline & Model1 & & Model2 & \\
\hline & Coefficient & Standard Errors & Coefficient & Standard Errors \\
\hline (Constant) & -0.262 & 0.257 & 0.355 & 0.262 \\
\hline Ma_ReinsRatio & $0.554^{\star * *}$ & 0.068 & $0.284^{\star * *}$ & 0.072 \\
\hline ROA & -0.356 & 0.261 & -0.262 & 0.238 \\
\hline Firm_Size & $0.025^{\star *}$ & 0.013 & -0.005 & 0.013 \\
\hline O_InsurLev & $0.051^{\star *}$ & 0.023 & $0.039^{*}$ & 0.022 \\
\hline Age & $0.032^{\star}$ & 0.017 & 0.021 & 0.017 \\
\hline O_LBC & 2.102 & 2.207 & 1.062 & 2.169 \\
\hline Ma_AnnualPG & -0.006 & 0.019 & 0.008 & 0.017 \\
\hline Ma_1YlossR & & & $0.081^{\star * *}$ & 0.069 \\
\hline Ma_2YlossR & & & 0.234 & 0.071 \\
\hline $\mathrm{N}$ & 168 & & 120 & \\
\hline Adjusted $\mathrm{R}^{2}$ & 0.317 & & 0.343 & \\
\hline P Value & $.000 \mathrm{~b}$ & & $.000 \mathrm{~b}$ & \\
\hline F Value ( $\mathrm{P}$ value) & 11.29 & & 7.533 & \\
\hline
\end{tabular}

Since reinsurance ratios are positive and significant with loss ratios indicating that in the marine portfolio the study fails to accept the null hypothesis meaning existence of asymmetric information in the marine portfolio. The finding of the study is consistent with Yan and Hong (2015). 


\section{Motor Portfolio}

Table 7 presents the results for OLS regression of motor portfolios. Reinsurance ratio is negative and not significant in both models indicating there is no presence of asymmetric information in marine portfolios. Further the results of the study deficit show that past loss ratios (one and two year) determine the present loss rather than reinsurance ceding has any influence on loss in the motor portfolio.

Table 7: Motor Portfolio

\begin{tabular}{lllll}
\hline & Model1 & & Model2 \\
\hline & Coefficient & Standard Errors & Coefficient & Standard Errors \\
(Constant) & $1.243^{* *}$ & 0.454 & $1.112^{* *}$ & 0.511 \\
Mo_ReinsRatio & -0.021 & 0.156 & -0.588 & 0.491 \\
ROA & -0.222 & 0.472 & -0.588 & 0.491 \\
Firm_Size & -0.035 & 0.024 & -0.026 & 0.026 \\
O_InsurLev & -0.012 & 0.043 & -0.075 & 0.047 \\
Age & 0.042 & 0.031 & -0.03 & 0.036 \\
O_LBC & -4.056 & 4.114 & -0.996 & 4.574 \\
Ma_AnnualPG & $-0.311^{\star * *}$ & 0.033 & $-0.297^{* * *}$ & 0.036 \\
Ma_1YlossR & & & $0.238^{*}$ & 0.135 \\
Ma_2YlossR & & & $0.241^{*}$ & 0.128 \\
\hline N & 168 & & 120 & \\
Adjusted R & 0.390 & & 0.441 & \\
P Value & $.000 \mathrm{~b}$ & & $.000 \mathrm{~b}$ & \\
F Value (P value) & 14.949 & & 13.179 & \\
\hline
\end{tabular}

Reinsurance ratios are found to be negative but not significant so a null hypothesis is accepted. As reinsurance ratio is not significant thus the study couldn't conclude whether there exists asymmetric information in the marine portfolio or not. The finding of the study is contradict with Yan and Hong (2015).

\section{Engineering Portfolio}

Table 8 presents the results for OLS regression of engineering portfolios. Reinsurance ratio is positive but not significant in both models indicating there doesn't exist asymmetric information in engineering portfolios. 
Table 8 : Engineering Portfolio

\begin{tabular}{lllll}
\hline & Model1 & & Model2 & \\
\hline & Coefficient & Standard Errors & Coefficient & Standard Errors \\
(Constant) & 1.167 & 1.825 & 1.849 & 2.222 \\
Mo_ReinsRatio & 0.736 & 0.534 & 0.899 & 0.63 \\
ROA & -0.772 & 1.968 & -1.009 & 2.225 \\
Firm_Size & -0.066 & 0.098 & -0.102 & 0.115 \\
O_InsurLev & -0.276 & 0.174 & $-0.334^{*}$ & 0.204 \\
Age & 0.129 & 0.126 & 0.123 & 0.147 \\
O_LBC & 15.435 & 17.148 & 20.341 & 20.483 \\
Ma_AnnualPG & -0.033 & 0.021 & $-0.037^{*}$ & 0.022 \\
Ma_1YlossR & & & 0.028 & 0.09 \\
Ma_2YlossR & & & -0.057 & 0.088 \\
N_ & 168 & & 120 & \\
Adjusted R ${ }^{2}$ & 0.052 & & -0.006 & \\
P Value & $.338 b$ & & $.515 b$ & \\
F Value (P value) & 1.146 & & 0.914 & \\
\hline
\end{tabular}

Reinsurance ratios are found to be positive but not significant with loss ratios indicating the study couldn't conclude the existence of asymmetric information in the engineering portfolio. The finding of the study is contradict with the study by Yan and Hong (2015).

\section{E. Miscellaneous Portfolio}

Table 9 presents the results for OLS regression of miscellaneous portfolios. Reinsurance ratio is not found to be positive and significant in both models. These results indicate there is no evidence of present asymmetric information in Nepalese reinsurance market in miscellaneous portfolios.

Table 9 : Miscellaneous Portfolio

\begin{tabular}{lllll}
\hline & Model1 & & Model2 & \\
\hline & Coefficient & Standard Errors & Coefficient & Standard Errors \\
(Constant) & -0.533 & 1.648 & -0.457 & 1.968 \\
Mo_ReinsRatio & -0.662 & 0.415 & -0.515 & 0.453 \\
ROA & -0.252 & 1.68 & -0.297 & 1.835 \\
Firm_Size & 0.111 & 0.084 & 0.09 & 0.098 \\
O_InsurLev & -0.234 & 0.147 & -0.249 & 0.169 \\
Age & -0.137 & 0.107 & -0.102 & 0.128 \\
O_LBC & -6.283 & 14.632 & 1.873 & 18.168 \\
Ma_AnnualPG & $-0.588^{* * *}$ & 0.154 & $-0.625^{* * *}$ & 0.171 \\
Ma_1YlossR & & & 0.057 & 0.089 \\
Ma_2YlossR & & & 0.218 & 0.235 \\
N & 168 & & 120 & \\
Adjusted R2 & 0.121 & & 0.112 & \\
P Value & $.000 \mathrm{~b}$ & & $.003 \mathrm{~b}$ & \\
F Value (P value) & 4.015 & & 2.938 & \\
\hline
\end{tabular}


Reinsurance ratios are found to be negative but not significant so a null hypothesis is accepted. Since reinsurance ratio is not significant thus the study couldn't conclude the existence of asymmetric information in the miscellaneous portfolio. The finding of the study is contradict with the finding of Yan and Hong (2015).

\section{F. Overall Portfolio}

Table 10 presents the results of OLS regression of reinsurance ceding on loss ratios of non life insurance companies of overall portfolios.

Table 10 : Overall Portfolio

\begin{tabular}{lllll}
\hline & Model1 & & Model2 \\
\hline & Coefficient & Standard Errors & Coefficient & Standard Errors \\
(Constant) & $-1.215^{* * *}$ & 0.414 & $-1.006^{* *}$ & 0.48 \\
Mo_ReinsRatio & $0.288^{* * *}$ & 0.12 & $0.255^{* *}$ & 0.128 \\
ROA & -0.349 & 0.43 & -0.311 & 0.448 \\
Firm_Size & $0.078^{* *}$ & 0.021 & $0.069^{* * *}$ & 0.025 \\
O_InsurLev & 0.067 & 0.044 & 0.05 & 0.048 \\
Age & 0 & 0.028 & 0.008 & 0.03 \\
O_LBC & $-10.541^{* * *}$ & 3.883 & -9.142 & 4.533 \\
Ma_AnnualPG & $-0.217^{* * *}$ & 0.042 & $-0.232^{* * *}$ & 0.045 \\
Ma_1YlossR & & & $0.141^{*}$ & 0.079 \\
Ma_2YlossR & & & $-0.149^{* *}$ & 0.074 \\
\hline N & 168 & & 120 & \\
Adjusted R2 & 0.25 & & 0.259 & \\
P Value & $.000 \mathrm{~b}$ & & $.000 \mathrm{~b}$ & \\
F Value (P value) & 8.293 & & 6.389 & \\
\hline
\end{tabular}

The coefficient of determination is 0.25 indicating the loss of insurance companies or companies are determined by the various variables under considerations. Both the statistics are significant at $1 \%$ level, indicating that model is best fit. Reinsurance ratio is positive and significant at the $1 \%$ level, supporting the hypothesis that there exists strong asymmetric information in the Nepalese reinsurance markets after controlling the information observable to reinsurers. The finding of the study is consistent with Yan and Hong (2015). Firm size is positive and significant at $1 \%$ level in both models indicating firms with larger in size have the larger loss. Negative coefficient of line of business concentrations indicate that higher the business concentration higher the risk as it produces higher losses. Similarly, negative and significant annual growth in premium rate indicates that insurers with higher total written premium growth rate will have lower loss ratios. 


\section{Conclusion}

Reinsurance is one of the major components of the insurance industry. Using the financial and operating firm level data of Nepalese nonlife insurance industry 12 years data from 2007/08 to 2018/19, the study examines whether there exists the asymmetric information in different portfolios including overall reinsurance market or not. The finding of the study reveals there exists asymmetric information in Nepalese reinsurance market. In accordance to different portfolios fire and marine have the strong evidence of existence of asymmetric information while engineering portfolios have weak evidence. In case of motor and miscellaneous there is no existence of asymmetric information.

Existence of asymmetric information is mostly an inevitable part as one party always tries to avoid information to others for the sake of benefit. However, the existence of asymmetric information to a large extent may lead to unhealthy relations between the parties and may bring the cold war distortion of relations. Thus, the finding of the studies is beneficial to the Nepalese nonlife insurers as insurers need to provide correct and accurate information to the reinsures. If the problems remain severe and for longer period well rated reinsurers gradually withdraw the business from Nepal which ultimately lead to Nepalese insurers moving towards low rated reinsurers around the globe especially in African region.

\section{Scope for future test}

The study concludes the existence of asymmetric information only but hasn't tested robustness by considering other methods like GMM, Quantile regression. Moreover, the study needs to test and confine the consequences of asymmetric information in the form of adverse selection and moral hazard in future research.

\section{References}

Aarbu, Karl Ove (2017). "Asymmetric Information in the Home Insurance Market," Journal of Risk and Insurance, 84(1), 35-72.

Adams, Michael B. and Stephen R. Diacon (2006). “Testing for Information Asymmetries in the United Kingdom Market for Property-liability Reinsurance," Discussion paper 1, Centre for Risk and Insurance Studies, University of Nottingham.

Adams, Mike and Wei Jiang (2016). "Do Outside Directors Influence the Financial Performance of Risktrading Firms? Evidence from the United Kingdom (UK) Insurance Industry," Journal of Banking \& Finance, 64(3), 36-51.

Akerlof, George, A. (1970). "The Market for "Lemons": Qualitative Uncertainty and Market Mechanism," Quarterly Journal of Economics, 84(3), 488-500.

Arellano, Manuel and Stephen Bond (1991). "Some Tests of Specification for Panel Data: Monte Carlo Evidence and an Application to Employment Equations," The Review of Economic Studies, 58(2), 277-297.

Arrow, Kenneth, J. (1963). "Uncertainty and the Welfare Economics of Medical Care," American Economic Review, 53(5), 941-973. 
BerryStölzle, Thomas R. and Patricia Born (2012). “The Effect of Regulation on Insurance Pricing: the Case of Germany." Journal of Risk and Insurance, 79(1), 129-164.

Blundell, Richard and Stephen Bond (1998), "Initial Conditions and Moment Restrictions in Dynamic Panel Data Models," Journal of Econometrics, 87(1), 115-143.

Bond, Eric W. and Keith J. Crocker (1997), "Hardball and the Soft Touch: The Economics of Optimal Insurance Contracts with Costly State Verification and Endogenous Monitoring Costs," Journal of Public Economics, 63(2), 239-264.

Carson, James M. and Robert E. Hoyt (1995). "Life Insurer Financial Distress: Classification Models and Empirical Evidence," Journal of Risk and Insurance, 62(4), 764-775.

Cohen, Alma and Peter Siegelman (2010), "Testing for Adverse Selection in Insurance Markets," Journal of Risk and Insurance, 77(1), 39-84.

Cummins, John David and Jean-François Outreville (1987). "An International Analysis of Underwriting Cycles in Property-liability Insurance," Journal of Risk and Insurance, 54(2), 246-262.

Doherty, Neil A. and James R. Garven (1995). "Insurance Cycles: Interest Rates and the Capacity Constraint Model," Journal of Business, 68(3), 383-404.

Doherty, Neil and Kent Smetters (2005). "Moral Hazard in Reinsurance Markets," Journal of Risk and Insurance, 72(3), 375-391.

Einav, L., Finkelstein, A., \& Levin, J. (2010). Beyond testing: Empirical models of insurance markets. Annu. Rev. Econ., 2(1), 311-336.

Garven, James R., James I. Hilliard, and Martin F. Grace (2014). "Adverse Selection in Reinsurance Markets," The Geneva Risk and Insurance Review, 39(2), 222-253.

Hardwick, Philip, Mike Adams, and Hong Zou (2011). "Board Characteristics and Profit Efficiency in the United Kingdom Life Insurance Industry," Journal of Business Finance \& Accounting, 38(78), 987-1015.

Harrington, Scott E. and Tong Yu (2003). "Do PropertyCasualty Insurance Underwriting Margins Have Unit Roots?, Journal of Risk and Insurance, 70(4), 715-733.

Hedengren, David and Thomas Stratmann (2016). "Is There Adverse Selection in Life Insurance Markets?” Economic Inquiry, 54(1), 450-463.

Jean-Baptiste, Eslyn L. and Anthony M. Santomero (2000). "The Design of Private Reinsurance Contracts,"Journal of Financial Intermediation", 9(3), 274-297.

Lee, Hsu-Hua and Chen-Ying Lee (2012). "An Analysis of Reinsurance and Firm Performance: Evidence from the Taiwan property-liability Insurance Industry," The Geneva Papers on Risk and InsuranceIssues and Practice, 37(3), 467-484.

Nishiyama, S., \& Smetters, K. (2005). Consumption taxes and economic efficiency with idiosyncratic wage shocks. Journal of political Economy, 113(5), 1088-1115.

Shiu, Yung Ming (2011). "Reinsurance and Capital Structure: Evidence from the United Kingdom Non life Insurance Industry," Journal of Risk and Insurance, 78(2), 475-494.

Shiu, Yung Ming and Becky F. Huang (2015). "Effects of Risk-Based Capital on Reinsurance Use: Evidence from the Taiwan Non-Life Insurance Industry," Academia Economic Papers, 43(3), 381-411. 
Shiu, Yung Ming and Ching -Yuan Hsiao (2014). "The Effect of Loss Ratio on the Use of Reinsurance," Academia Economic Papers, 42(3), 435-483.

Su, L., \& Spindler, M. (2013). Nonparametric testing for asymmetric information. Journal of Business \& Economic Statistics, 31(2), 208-225.

Su, Liangjun and Martin Spindler (2013). "Nonparametric Testing for Asymmetric Information," Journal of Business and Economic Statistics, 31(2), 208-225.

Upreti, V., \& Adams, M. (2015). The strategic role of reinsurance in the United Kingdom's (UK) non-life insurance market. Journal of Banking \& Finance, 61, 206-219.

Warner, J. B. (1977). Bankruptcy costs: Some evidence. The journal of Finance, 32(2), 337-347.

Wooldridge, J. M. (2016). Introductory econometrics: A modern approach. Nelson Education.

Yamamoto, Y., Harada, S., Yamamoto, D., Honda, W., Arie, T., Akita, S., \& Takei, K. (2016). Printed multifunctional flexible device with an integrated motion sensor for health care monitoring. Science advances, 2(11), 16-73.

Yan, Zhiqiang (2013). “Testing for Moral Hazard in Reinsurance Markets," Managerial Finance, 39(8), 696-713.

Yan, Zhiqiang and Liang Hong (2015). “Testing for Asymmetric Information in Reinsurance Markets," The Geneva Papers on Risk and Insurance Issues and Practice, 40(1), 29-46. 